\title{
Diskresi Sebagai Kebebasan Bertindak Pemerintah (Tinjauan Konseptual dan Empris)
}

\author{
Oleh : \\ Yusri Munaf \\ Program Pasca Sarjana Ilmu Pemerintahan \\ Universitas Islam Riau \\ Yusri.ip@soc.uir.ac.id
}

\begin{abstract}
Abstrak
Konsep diskresi adalah konsep tentang kekuasaan, dalam hal ini adalah kekuasaan pemerintah dalam arti sempit (bestuur). Diskresi sebagai konsep kekuasaan adalah kekuatan dalam pengertian spesifik, tidak dalam pengertian rutin. Kekuasaan diskresi disini adalah kebebasan bertindak pemerintah. Kebebasandisini memilik pengertian yang netral, yaitu menggambarkan adanya suatu kekuasaan memilih berbagai tindakan. Pembahasan ini memiliki tujuan untuk memberikan kejelasan atas konsep kekuasaan diskresi dalam penyelenggaraan pemerintahan yang masih kontroversial dari berbagai aspek supaya konsep kekuasaan diskresi tersebut tidak hanya akseptabel secara kekuasaan, tetapi juga sekaligus akseptabel secara yuridis dan secara moral/etis. Pembahasan dilengkapi dengan aspek empiris penerapan diskresi pada penyelenggaraan pemerintah daerah di Indonesia. Pemerintah pusat menjamin perlindungan kepada kepala daerah yang melakukan diskresi untuk mempercepat pembangunan dan kesejahteraan masyarakat. Kementrian Dalam Negeri, menjelasakan saat ini sudahada Undang Undang Nomor 23 tahun 2014 tentang Pemerintahan Daerah, dan Undang-Undang Nomor 30 tahun 2014 tentang Administrasi Pemerintahan, yang menjamin diskresi oleh kepala daerah. Pada prinsipnya Undang-Undang Nomor23 tahun 2014 dan Undang-Undang Nomor 30 tahun 2014 menjadi pedoman kepala daerah untuk berinovasi dan melakukan diskresi tanpa ragu dan takut. Akan tetapi kekuasaan diskresi pemerintah harus tetap beroperasi di bawah suatu sistem hukum yaitu the rule of law. Di bawah preskripsi asas the rule of law, kekuasaan diskresi pemerintah hidup berdampingan dengan asas the rule of law, kekuasaan diskesi pemerintah hidup berdampingan dengan asas responsible goverment.
\end{abstract}

Kata Kunci : Diskresi, Kebebasan Bertindak, Pemeritahan.

\begin{abstract}
The concept of discretion is the concept of power, in this case the power of government in the sense of narrow (bestuur). Discretion as a concept of power is power in a specific sense, not in the routine sense. The power of discretion here is the freedom of government action. Freedom here has a neutral understanding, which describes the existence of a power to choose various actions. This discussion aims to provide clarity on the concept of discretionary power in the administration of government that is still controversial from various aspects so
\end{abstract}


that the concept of power of discretion is not only acceptable power, but also atthe same time acceptable juridically and morally / ethically. The discussion is complemented by empirical aspects of the application of discretion to the implementation of local government in Indonesia. The central government guarantees the protection of discretionary regional heads to accelerate the development and welfare of the people. Ministry of Home Affairs, explains that there are now Law No. 23 of 2014 on Regional Government, and Law No. 30 of 2014 on Government Administration, which guarantees discretion by the regional head. In principle, Law No. 23 of 2014 and Law No. 30 of 2014 serve as guidelines for the regional head to innovate and undertake discretion without hesitation and fear. However, the government's discretionary powers must remain operative under a legal system of the rule of law. Under the prescriptions of the rule of law principle, the government's discretionary powers coexist with the rule of law principle, the power of government discretion coexists with the principle of responsible goverment.

Keywords: Discretion, Freedom of Action, Government.

\section{Latar Belakang}

Tulisan ini membahas isu konsep kekuasaan diskresi pemerintah. Pembahasan ini memiliki tujuan untuk memberikan kejelasan atas konsep kekuasaan diskresi dalam penyelenggaraan pemerintahan yang masih kontroversial dari berbagai aspek supaya konsep kekuasaan diskresi tersebut tidak hanya akseptabel secara kekuasaan, tetapi juga sekaligus akseptabel secara yuridis dan secara moral/etis. Pembahasan dilengkapi dengan aspek empiris penerapan diskresi pada penyelenggaraan pemerintah daerah di Indonesia.

Konsep kekuasaan tidak pernah berada dalam makna yang hampa, bahkan dalam pengertiannya yang sederhana sekalipun sebagai "kemampuan berbuat atau bertindak". Pemahaman kekuasaan oleh umum itu berbicara tentang

${ }^{1}$ A.S. Hornby, Oxford Advanced Dictionary, Oxford: Oxford University Press, 1983, Hal. 652 kekuasaan dalam hubungan dengan interaksi sosial. Kekuasaan memperlihatkan suatu kemampuan yang terdapat di dalam hubungan antarmanusia, suatu hubungan sosial sebagai wadah penerapan kekuasaan. Dalam perkembangannya, teori pemisahan kekuasaan di dalam praktik tidak dapat diterapkan secara utuh dan konsekuen oleh karenayang terjadi cenderung menyerupai pembagian kekuasaan. Kini dengan dianutnya konsep negara kesejahteraan (welfare state) mengakibatkan terjadinya pergeseran sebagai kekuasaan penyelenggaraan pemerintah negara.

Apabila sebelumnya kekuasaan penyelenggaraan pemerintahan dalam hal ini pemerintah (besture) diatur agar tidak demikian dominan, didalam negara kesejahteraan justru diberi peluang untuk menjadi dominan dengan penyebabnya adalah pemberian legitimasi bagi adanya kekuasaan diskresi pemerintah.

Istilah diskresi yang

dipergunakan di sini merupakan sinonim istilah discretion dalam bahasa inggris. Konsep diskresi yang 
dipergunakan disini adalah konsep tentang kekuasaan (dalam bahasa Inggris disebut discretion power dan dalam bahasa Prancis disebut pouvoir discretion naire). Secara terminologis makna intristik diskresi selalu mengandung konotasi kekuasaan. Kekuasaan disini dimaknai dalam bentuk hubungan antara pihak yang memerintah (theruler) dan pihak yang diperintah (the ruled), satu pihak yang memberiperintah dan satu pihak yang mematuhi perintah.

Sebagaimana telah dijelaskan sebelumnya, konsep diskresi adalah konsep tentang kekuasaan, dalam hal ini adalah kekuasaan pemerintah dalam arti sempit (bestuur). Diskresi sebagai konsep kekuasaan adalah kekuatan dalam pengertian spesifik, tidak dalam pengertian rutin. Kekuasaan diskresi disini adalah kebebasan bertindak pemerintah. Kebebasan disini memilik pengertian yang netral, yaitu menggambarkan adanya suatu kekuasaan memilih berbagai tindakan.

Untuk lebih komprehensif, tulisan ini mencoba memberikan gambaran secara konseptual dan empiris sebagai berikut.

\section{Landasan Teoritis dan Yuridis Kebebasan Bertindak Pemerintah.}

Kekuasaan diskresi adalah jenis kekuasaan pemerintah yang spesifik dan make sense tidak hanya secara kekuasaan, tetapi juga secara yuridis dan filosofis. Dari perspektif analitik, perluasan fungsi pemerintah dalam menjawab makin luasnya tuntutan masyarakat teradap pemerintah merupakan dasarlahirnya konsep kekuasaan diskresi sebagai kebebasan pemerintah.
Sedangkan dari perspektif yuridis, kekuatan diskresi adalah sebuah keharusan karena kurang memadainya skema legislasi dari legislator untuk diimplementasikan oleh pemerintah atau dengan kata lain adanya kaidah kabur dan gap. Sebagai bentuk kekuasaan yuridis, pemerintah selaku pembuat tindakan diskresi memiliki imunitas atas tindakan tesebut.

Adapun dari perspektif, kekuasaan diskresi adalah kekuasaan yang bertujuan, bukan kekuasaan buta. Asepk aksiologi dari kekuasaan diskresi adalah pengupayaan tujuan hidup paling fundamentel dari negara yaitu public good. Penertian yang fundamental dari negara, yaitu asas legalitas merupakan saranadalam rangka public good. Oleh sebab itu dalam public good tidak dapat dikesampingkan oleh asas legalitas (tujuan tidak boleh dikesampingkan oleh sarana). ${ }^{2}$

Dasar teori dari diskresiadalah pertimbangan mengenai perkembangan situasi dan kondisi. Perubahan situasi dan kondisi adalah keniscayaan. Sementara perubahan peraturan tidak niscaya serta merta dapat terjadi. Dalam konteks demikian Fatovic memberi kaidah :

"Designed for the ordinary and the normal, law cannot always provide for such extraordinary occurrences in spite of its aspiration to comprehensiveness" 3

\footnotetext{
${ }^{2}$ Krishna D. Darumurti, 2012. Kekuasaan Diskresi Pemerintah. PT. Citra Aditya Bakti. Bandung Hal. 103.

${ }^{3}$ Clement Fatovic, Outside the Law :

Executive and Emergency Power, Baltimore
} 
Hakikat kekuasaan diskresi pada pemerintah memperlihatkan fungsinya dalam hal:

1. Menyelesaikan berbagai permasalahan pelik yang membutuhkan penanganan secara cepat.

2. Menyelesaikan soal-soal genting yang timbul dengan sekonyong-konyong dan yang peraturan penyelesaiannya belum ada. ${ }^{4}$

Kekuasaan diskresi pemerintah dalam pengertian sebagai kebebasan bertindak pemerintah memilik dua bentuk, yaitu :

1. Kebebasan Kebijakan (beleidsvrijheid)

Kebebasan kebijakan (wewenang diskresi dalam arti sempit) ada manakala peraturan perundangundangan memberi kewenangan tertentu kepada organ pemerintahan sementara organ tersebut bebas untuk menggunakannya meskipun syarat-syarat bagi penggunaannya secara sah dipenuhi.

2. Kebebasan penilaian (beoordelingsvrijheid)

Kebebasan penilaian (wewenang diskresi tidak dalam arti sesungguhnya) ada manakala sejauh menurut hukum diserahkan kepada organ pemerintahan untuk

The John Hopkins University Press, 2009, Hal. 2

${ }^{4}$ Saut P. Panjaitan, Maksna dan Peranan Freies Ermessen dalam Hukum Administrasi Negara. dalam S.F. Marbun, et.al. Eds. Op.cit h.107 menilai secara mandiri dan eksklusif apakah syarat-syarat bagi pelaksanaan suatu kewenangan secara sah telah dipenuhi. $^{5}$

Berbicara mengenai kebebasan bertindak pemerintah, maka akan memunculkan pikiran kita tentang adanya suatu gambaran kekuasaan aparatur yang mengambil suatu keputusan yang seolah-olah tidak melalui atau tidak sesuai dengan jalur hukum yang telah digariskan, atau aparatur tersebut bertindak menegakkan hukum positif yang seharusnya ditegakkan.

Padangan teoritis pemikiranpemikiran hukum diharapkan dapat memberikan gambaran tentang peranan dari aparatur pemerintah di dalam melaksanakan tugas. Padangan hukum legalitas, hukum diidentikan dengan undang-undang. Sistem hukum dipandang sebagai suatu struktur tertutup yang logis.

Tidak bertentangan satu sama lain, hukum dipandang sebagai perangkat aturan-aturan yang diharapkan agar ditaati oleh para anggota masyarakat. Penerapan model pengkajian di dalam masyarakat, hanya terlihat dan menganggap hukum yang ada di masyarakat sudah diwadahi oleh norma-norma hukum yang memadai, dan hukum sudah dilengkapi dengan kelengkapan-kelengkapan teknis yuridis yang sudah mapan. Hukum disini sudah merupakan obat dari segala macam penyakit yang melanggar norma-norma masyarakat, sehingga tak satupun persoalan di

\footnotetext{
${ }^{5}$ Menurut N.M. Spelt \& J.B.J.M. ten Berge dalam Philipus M. Hadjon, Pemerintahan menurut hukum (Wet-en Rechtmatig Bestuur), Surabaya: Yuridika, 1992, hh 6-7.
} 
masyarakat yang tidak teratasi. Dengan demikian tak mungkin bagi aparatur pemerintah untuk dapat bertindak atas inisiatif sendiri untuk mengatasi persoalan yang muncul di tengah-tengah proses kehidupan masyarakat, karena bagi aparatur pemerintah tinggal mencocokkan antara persoalan yang munculdengan aturan yang ada karena sebagaimana dijelaskan bahwa hukum adalah obat dari segala macam penyakit. Maka tidak mengherankan kalau kehidupan hukum itu sering mengalami ketidak cocokan dengan kenyataankenyataan yang telah berlaku di dalam kehidupan bermasyarakat atau bahkan belum dibuat oleh pembuat peraturan perundang-undangan (legislative) sehingga tak mustahil adanya ketidakcocokan atau kevakuman hukum

Oleh karena pola pemikiran legalitas yuridis ini bertahun-tahun menguasai darah daging para aparatur pemerintah sehingga inisiatif dari mereka tidak bertumbuh, hanya selalu berpatokan pada hukum, padahal kita tahu bahwa perkembangan dimasyarakat semakin hari lebih jauh bahkan melampaui, sehingga hukum diharuskan mengikuti perkembangan itu, namun kenyataan hukum sangat lamban. Kebebasan bertindak pemerintah (diskresi) sudah jelas tak sesuai dengan pola pikir yang demikian (legalitas), karena pola pikir pada diskresi adalah pola pikir yang menyesuaikan antara kenyataan proses kehidupan dengan asas-asas dan politik hukum yang lebih luas, karena hukum itu untuk masyarakat bukan masyarakat untuk hukum.
Roscoe Pound berpendapat bahwa tujuan hukum harus ditelaah dalam kerangka kebutuhan atauuntuk kepentingan sosial. Di dalam golongan kepentingan sosial tercakup antara lain kepentingan akan keamanan umum, kehidupan pribadi, perlindungan terhadap moral, konservasi sumber-sumber daya serta kepentingan-kepentingan dalam perkembangan ekonomi, sosial, budaya.

Sehubungan social jurisprudence itu, menurut ajaran hukum fungsional, hukum dipandang sebagai instrument untuk mengarahkan atau pencapaian tujuan masyarakat. ${ }^{6}$ Pada pendekatansecara fungsional ini para pejabat administrasi terutama di daerah harus senantiasa mengukur norma-norma hukum dan factor-faktor lain yang mempengaruhi (sosial, budaya dan sebagainya) berdasarkan efektivitasnya, bagaimana hukum itu bekerja dalam kenyataan, sehingga apabila antara hukum itu sudah sesuai lagi dengan perkembangansosial atau malah menghambat pembangunan atau bahkan belum ada, maka diharapkan bagi aparatur pemerintah harus berani untuk menyisihkan atau dengan inisiatifnyadapat menetapkan suatu kebijakan untuk mengatasi kesenjangan tadi.

Oleh sebab itu bagi seorang aparatur Negara baik dipusat maupun di daerah dapat dengan cepat atas inisiatifnya sendiri bertindak untuk dapat memenuhi keharusan tersebut, Inisiatif ini dikenal dengan istilah kebebasan bertindak atau diskresi

\footnotetext{
${ }^{6}$ M. Faal, Diskresi Kepolisian, Jakarta, PT. Pradnya Paramita, 1991, hlm. 1
} 
dalam bahasa Prancis dikenal dengan istilah freis ermessen.

Landasan hukum suatu diskresi ini tercermin dalam :

1. UUD 1945, Pasal 22 ayat 1, bahwa dalam hal-hal kepentingan yang memaksa, Presiden berhak menetapkan peraturan pemerintah pengganti undang-undang. Dalam Pasal 22 ayat 1 ini ada unsur kebebasan bertindak pemerintah, secara khusus Presiden yang nota bene sebagai penanggung jawab atas bangsa dan Negara kesatuan Republik Indonesia dalam hal menciptakan kondisi yang dapat

menguntungkan rakyat sehingga Presiden diberi suatu kebebasan untuk menetapkan suatu bentuk kebijakan yang dinamakan Perpu sebagai antisipasi adanya kondisi yang tiba-tiba timbul tanpa harus menunggu perintah dari badan kenegaraan yang diserahi tugas/fungsi legislative.

2. Secara khusus dalam rangka otonomi daerah, UUD 1945 Pasal 18 sebagai aturan yang juga menjadi kebijakan dalam rangka meningkatkan kesejahteraan masyarakat, yang kemudian ditindaklanjuti dengan aturanaturan yang lebih konkrit (yang ada di bawah UUD 1945), salah satunya UU No. 32 Tahun 2004 sebagaimana telah diganti dengan UU No.

23 Tahun 2014.

3. Undang-Undang No. 32 tahun 2004 sebagaimana telah diganti dengan UU No. 23 Tahun 2014 tentang Pemerintahan Daerah, merupakan perpanjangan tangan dari UUD 1945 Pasal 18, pada prinsipnya dalam undang-undang ini memberikan keleluasaan sebagaimana dalam UUD 1945 Pasal 18, bagi aparat pemerintah daerah dalam pengertian luas dan sempit untuk dapat memberdayakan potensi daerah yang ada menurut prakarsa sendiri dalam rangka mensejahterakan rakyat di daerah sesuai dengan kondisi daerah dalam kerangka Negara kesatuan republik Indonesia.

Pergeseran konsepsi nachwachtersstaat (Negara peronda) ke konsepsi wefare state membawa pergeseran pada peranan dan aktivitas pemerintah. Pada konsepsi nachwachtersstaat berlaku prinsip staatsonthouding yaitu pembatasan Negara dan pemerintah dari kehidupan social dan ekonomi masyarakat. Sedangkan pada konsepsi wefare state pemerintah diberi kewajiban untuk mewujudkan bestuurszorg (kesejahteraan umum), yang untuk itu kepada pemerintah diberikan kewenangan untuk campur tangan (staatsbemoeienis) dalam segala lapangan kehidupan masyarakat. Artinya pemerintah dituntut untuk bertindak aktif di tengah dinamika kehidupan masyarakat. ${ }^{7}$

\footnotetext{
${ }^{7}$ Ridwan HR, Hukum Administrasi Negara, Jakarta, PT RajaGrafindo Persada, 2007 
Pada dasarnya setiap campur
tangan pemerintah ini harus didasarkan pada peraturanperundangundangan yang berlaku sebagai perwujudan dari asas legalitas, yang menjadi sendi utama Negara hukum. Akan tetapi, karena ada keterbatasan dari asas ini atau karena adanya kelemahan dan kekurangan yang terdapat pada peraturan perundangundangan, maka kepada pemerintah diberi kebebasan freies Ermessen, yaitu kemerdekaan pemerintah untuk dapat bertindakatas inisiatif sendiri dalammenyelesaikan persoalan-persoalansosial. ${ }^{8}$

Freies

Ermessen

(diskresionare) merupakan salah satu sarana yang memberikan ruang gerak bagi pejabat atau badan-badan administrasi Negara untuk melakukan tindakan tanpa harus terikat sepenuhnya pada undangundang. Dalam praktek, freies Ermessen ini membuka peluang terjadinya benturan kepentingan antara pemerintah dengan warga negara.

Pemerintah

dalam menjalankan aktifitasnya terutama dalam mewujudkan tujuan-tujuan Negara melalui pembangunan, tidak berarti pemerintah dapat bertindak semena-mena, melainkan sikap tindak itu haruslah dipertanggung jawabkan. Artinya meskipun intervensi pemerintah dalam kehidupan warga Negara merupakan kemestian dalam konsepsi welfare state, tetapi pertanggungjawaban setiap tindakan pemerintah juga merupakan keharusan dalam Negara hukum yang menjunjung tinggi nilainilai kebenaran dan keadilan. Nilai-

${ }^{8}$ Ibid, hlm. 241 nilai kebenaran dan keadilan inilah yang menjadi dasar bertindak pejabat administrasi dalam penyelenggaraan pemerintahan sebagai perwujudan dari Asas-asas Umum Pemerintahan Yang Layak (AAUPL).

\section{Tinjauan Empiris}

Pemerintah pusat menjamin perlindungan kepada kepala daerah yang melakukan diskresi untuk mempercepat pembangunan dan kesejahteraan masyarakat. Kementrian Dalam Negeri, menjelasakan saat ini sudah ada Undang Undang Nomor 23 tahun 2014 tentang Pemerintahan Daerah, dan Undang-Undang Nomor 30tahun 2014 tentang Administrasi Pemerintahan, yang menjamin diskresi oleh kepala daerah. Pada prinsipnya Undang-Undang Nomor 23 tahun 2014 dan Undang-Undang Nomor 30 tahun 2014 menjadi pedoman kepala daerah untuk berinovasi dan melakukan diskresi tanpa ragu dan takut.

Undang Undang Administrasi Pemerintahan menjamin diskresi yang dilakukan kepala daerah, dan memastikan kewenangan untuk mengambil kebijakan saatdiperlukan, untuk mempercepat pembangunan dan kesejahteraan masyarakat. Diskresi juga dapat dilakukan jika belum ada Undang- Undang yang mengatur suatu permasalahan, atau aturan yang ada tidak lengkap dan jelas, sehingga menyebabkan stagnasi. Diharapkan kepala daerah untuk tidak ragu dan takut untuk melakukan inovasi, dan mengoptimalkan potensi yang ada, bahkan Presiden Joko Widodo telah memberikan instruksi khusus terkait diskresi kepada Polri dan Kejaksaan 
Agung. Intinya, diskresi dan tindakan administrasi pemerintahan tidak dapat dipidanakan.

\section{Pemerintah}

Daerah merupakan institusi yang sangat strategis dalam manajemenbernegara. Jalannya kehidupan bernegara akan ditentukan dengan efektif tidaknya manajamen

pemerintahan.

Pembangunan

infrastruktur (jembatan, jalan, rumah sakit, pelabuhan, dsb), penerbitan KTP/Akta Kelahiran/Kartu Keluarga, pelayanan kesehatan, penyelenggaraan pendidikan, pengurusan perizinan, dll akan berkualitas sepanjang organisasi pengelolanya, yakni Pemerintah diselenggarakan dengan manajemen yang berkualitas pula.

Pencapaian tujuan (goal setting) yang dicanangkan oleh Pemerintah harus jelas dan terukur yang termaktub dalam visi dan misi bernegara dalam UUD 1945 dan visi misi Pemerintah setiap awal rezim Pemerintah yang berkuasa (5 tahun). Visi dan misi tersebut akan diejawantahkan dalam program perencanaan pembangunan (planning) yang dicanangkan berdasarkan jangka waktunya, pendek, menengah dan panjang yang berupa Rencana Pembangunan Jangka Panjang Nasional (RPJP Nasional), Rencana Pembangunan Jangka Menengah Nasional (RPJM Nasional), Rencana Kerja Pemerintah (RKP), RencanaStrategis, dan Rencana Kerja. Selanjutnya, implementasi dari program perencanaan harus didukung oleh organisasi, aparatur Pemerintah yang profesional dan akuntabel, tersedianya peraturanyang jelas dan berkepastian hukum, maupun tersedianya anggaran yang berbasis kinerja (organizing). Terakhir, pelaksanaan program yang dicanangkan harus dipastikan progres dan capaiannya agar dapat menghasilkan layanan dan pembangunan yang berkualitas yang dirasakan oleh setiap lapisan masyarakat.

Tidak mudah untuk mewujudkan hasil pembangunan yang berkualitas. Terdapat beberapa faktor yang mempengaruhi tingkat keberhasilan suatu program Pemerintah, salah satunya adalah profesionalisme dan integritas Pejabat Pemerintahan. Profesionalisme dalam hal ini berarti bekerja tuntas dan akurat atas dasar kompetensi terbaik dengan penuh tanggung jawab dan komitmen yang tinggi dalam menyelesaikan setiap misi yang diemban sesuai tugas dan fungsi Pejabat Pemerintahan dimaksud. Integritas dalam hal ini adalah segala tindakan Pejabat Pemerintahan dalam menyelesaikan setiap pekerjaan kedinasan berdasarkan semangat, perilaku, dan tindakan yang sesuai dengan prinsipprinsip moral. Sebagaimana kita ketahui bahwa prinsip moral Pejabat Pemerintahan yang menjadi patokan utama adalah penerapan Asas-asas Umum Pemerintahan yang Baik (AUPB). AUPB adalah prinsip yang digunakan sebagai acuan penggunaan wewenang bagi Pejabat Pemerintahan dalam mengeluarkan keputusan dan/atau tindakan dalam penyelenggaraan pemerintahan sebagaimana tercantum dalam Undang-Undang Nomor 30 Tahun 2014 tentang Administrasi Pemerintahan.

AUPB tersebut, meliputi: 
1. kepastian hukum;

2. kemanfaatan;

3. ketidakberpihakan;

4. kecermatan;

5. tidak menyalahgunakan

kewenangan;

6. keterbukaan;

7. kepentingan umum; dan

8. pelayanan yang baik.

Dalam pelaksanaan program pembangunan, baik dalam tahap perencanaan, eksekusi, maupun monitoring, Pejabat Pemerintahan harus selalu mengacu kepada peraturan perundang-undangan dan AUPB. Nilai-nilai dalam AUPB sifatnya adalah kumulatif artinya segala tindakan, perbuatan, atau kebijakan yang dikeluarkan oleh Pejabat Pemerintahan tidak boleh melenceng satupun dari nilai-nilai AUPB.

Sedangkan peraturan perundang-undangan dimaksud meliputi peraturan perundangundangan yang menjadi dasar kewenangan dan peraturan perundang-undangan yang menjadi dasar dalam menetapkan dan/atau melakukan keputusan dan/atau tindakan. Kewenangan yang dimiliki oleh Pejabat Pemerintahan dapat berasal dari kewenangan atributif, delegatif, maupun mandat. Ketiga kewenangan tersebut harus jelas dasar hukumnya, agar segala kebijakan/keputusan yang dikeluarkan oleh Pejabat Pemerintahan memiliki kekuatan hukum yang kuat dan efektif dilaksanakan.

Namun, dalam kondisi tertentu, seringkali kita jumpai beberapa program pembangunan yang dilaksanakan oleh Pemerintah terhambat pelaksanaanya. Salah satu faktornya adalah belum jelas dan/atau belum lengkapnya aturan hukum yang berlaku yang menjadi dasar bagi setiap tindakan dan/atau keputusan yang harus diambil oleh Pejabat Pemerintahan dalam mendukung kesuksesan program pembangunan.

Dalam kondisi ini, UU No 30 Tahun 2014 tentang Administrasi Pemerintahan memberikan jalan keluar kepada Pejabat Pemerintahan untuk tetap bisa mengeluarkan keputusan dan/atau tindakan dalam rangka mendukung kelancaran pelaksanaan program Pemerintah sepanjang memberikan kemanfaatan umum dan sesuai AUPB, yakni mengeluarkan diskresi. Sesuai Pasal 1 angka 9 UU No 30 Tahun 2014 tentang Administrasi Pemerintahan bahwa diskresi adalah keputusan dan/atau tindakan yang ditetapkan dan/atau dilakukan oleh Pejabat Pemerintahan untuk mengatasi persoalan konkret yang dihadapi dalam penyelenggaraan pemerintahan dalam hal peraturan perundang-undangan yang memberikan pilihan, tidak mengatur, tidak lengkap atau tidak jelas,dan/atau adanya stagnasi pemerintahan. Kewenangan diskresi seringkali terbit manakala suatu program pemerintah tidak berjalan optimal dan mengarah kepada stagnasi akibat dari peraturan yang berlaku tidak lengkap atau tidak jelas. Namun, diskresi janganlah disalahartikan bahwa Pejabat Pemerintahan bisa sebebas-bebasnya mengeluarkan keputusan dan/atau tindakan atas kehendaknya sendiri tanpa dilandasi dengan koridor yang harus dipatuhi, yakni demi 
kepentingan umum, dalam batas wilayah kewenangannya, dan tidak melanggar AUPB. Setiap kewenangan dalam negara hukum tidak dikenal adanya wewenang yang sebebas-bebasnya. Wewenang (termasuk wewenang terikat) selalu memiliki batasan yang diperintahkan oleh peraturan perundang-undangan. Adapun syarat-syarat yang harus dipenuhi oleh Pejabat Pemerintahan dalam menggunakan diskresi sebagai berikut (Pasal 24 UU No 30 Tahun 2014 tentang Administrasi Pemerintahan) :

1. sesuai dengan tujuan Diskresi;

2. tidak bertentangan dengan ketentuan peraturan perundang-undangan;

3. sesuai dengan AUPB;

4. berdasarkan alasan-alasan yang objektif;

5. tidak menimbulkan Konflik Kepentingan; dan

6. dilakukan dengan iktikad baik.

Posisi diskresi dengan kewenangan pada umumnya adalah sebagai pelengkap kewenangan terikat yang sudah ada dan sebagai solusi bagi Pejabat Pemerintahan atas persoalan yang terjadi di lapangan, yang membutuhkan pertimbangan subjektif Pejabat Pemerintahan demi kelancaran tugas-tugasnya. Pejabat Pemerintahan harus terlebih dahulu melaksanakan tugas-tugasnya berdasarkan kewenangan terikatyang dimiliki sebelumnya yang telah diatur dalam peraturan perundangundangan (atribusi, delegasi, mandat), baru kemudian dalam hal kondisi membutuhkan pertimbangan subjektif Pejabat Pemerintahan atas suatu persoalan, maka perlu adanya diskresi Pejabat Pemerintahan sepanjang memenuhi persyaratan di atas.

Masyarakat atau stakeholders lainnya selaku penerima layanan Pejabat Pemerintahan (servant taker) dapat mengontrol setiap tindakan dan/atau keputusan Pejabat Pemerintahan apakah tetap berjalan atau keluar dalam koridor yang telah diatur dalam peraturan perundangundangan. Pelaksanaan kewenangan terikat yang berlaku maupun diskresi tentunya menimbulkan implikasi baik positif dan negatif, sehingga masyarakat atau stakeholders lainnya dapat menilai apakah Pejabat Pemerintahan yang telah mengeluarkan keputusan dan/atau tindakan telah melampaui wewenangnya atau tidak dengan indikator sebagai berikut:

1. bertindak melampaui batas waktu berlakunya wewenang yang diberikan oleh ketentuan peraturan perundangundangan;

2. bertindak melampaui batas wilayah berlakunya wewenang yang diberikan oleh ketentuan peraturan perundang-undangan;

3. tidak sesuai dengan maksud, tujuan, substansi, serta dampak administrasi dan keuangan dikeluarkannya diskresi.

Dalam hal terdapat Pejabat Pemerintahan terbukti melakukan tindakan dan/atau keputusan yang melampaui wewenangnya, maka akibat hukum dari keputusan Pejabat Pemerintahan tersebut adalah tidak sah, dan masyarakat dan/atau stakholders terkait dapat mengajukan 
pembatalan atas dikeluarkannya keputusan dimaksud.

Penyimpangan terhadap penggunaan diskresi dapat diuji melalui peradilan dan pembuat kebijakan akan dibebani tanggung jawab. Ada dua bentuk tanggung jawab, yakni tanggung jawab jabatan dan tanggung jawab pribadi. Tanggung jawab jabatan terjadiketika pembuat kebijakan menggunakan diskresi untuk dan atas nama jabatan, sedangkan tanggung jawab pribadi diterapkan dalam hal pembuat kebijakan melakukan tindakan maladministrasi.

Agar diskresi keputusan dan/atau tindakan Pejabat Pemerintahan mewujudkan tata pemerintahan yang baik berjalan efektif, maka Pejabat Pemerintahan dalam melakukannya harus demi kepentingan umum, dilakukan secara transparan, serta diupayakan mengikutsertakan partisipasi publik secara luas.

Oleh sebab itu kekhawatiran banyak daerah untuk mencairkan anggaran dalam APBD guna pembiayaan program dan kegiatan daerah, yang memicu kelambanan penyerapan anggaran, sejatinya tak beralasan. Pasalnya, dengan telah berlakunya Undang-Undang Nomor 23 tahun 2014 jis UU No 2/2015 dan Undang-Undang Nomor 9 tahun 2015 tentang Pemerintahan Daerah (UU Pemda) dan Undang-Undang Nomor 30 tahun 2014 tentang Administrasi Pemerintahan (UU AP), di satu sisi telah terjadi perluasan wilayah administrasi dalamkebijakan penganggaran dan di sisilain terjadi penyempitan wilayah pidana korupsi.
Pengaturan perihal inovasi daerah pada Bab XXI Pasal 386-390 UU Pemda dan diskresi pada Bab VI Pasal 22-32 UU AP telah mengontrol secara ketat kriminalisasi kebijakan pemerintah daerah, termasuk dalam pencairan anggaran daerah.Kelahiran ketentuan-ketentuan tersebut sejatinya ingin mengonstruksi garis demarkasi baru wilayah administrasi kebijakan dengan wilayah pidana korupsi yang selama ini dianggap kabur.

Akan tetapi pada kenyataannya masih memunculkan ketakutan berlebihan kepala daerah. Kian meluasnya wilayah administrasi di ranah kebijakan pemda tersebut, meskipun sering dianggap bertentangan dengan semangat anti korupsi, sejatinya secara normatif telah cukup memproteksi pelaksanaan program dan kegiatan di daerah dari potensi kriminalisasi. Dengan demikian, tak ada alasan bagi ketakutan dikriminalisasi bagi aparatur sipil negara dalam pencarian anggaran daerah yang kini menjadi keprihatinan bagi pemerintah.

Tersendatnya pencairan anggaran daerah oleh sejumlah daerah telah menyebabkan banyak daerah tak mampu mengeksekusi program dan kegiatan yang telah direncanakan melalui Rencana Pembangunan Jangka Menengah daerah (RPJMD), Rencana Kerja Pembangunan Daerah (RKPD), dan Rencana Strategis Satuan Kerja Pemerintah Daerah (Renstra SKPD). Hal ini juga dinilai telah menjadi salah satu pemicu kianmemburuknya nilai tukar rupiah terhadap dollar AS akibat anggaran daerah tak mampu memberikanstimulus fiskal. 
Pasal 386 UU Pemda dengan tegas menyatakan, dalam rangka peningkatan kinerja penyelenggaraan pemerintahan daerah, pemerintah daerah dapat melakukan inovasi. Inovasi merupakan semua bentuk pembaruan dalam penyelenggaraan pemerintahan yang harus berpedoman pada sejumlah prinsip penting, seperti peningkatan efisiensi, perbaikan efektivitas, perbaikan kualitas pelayanan, dan sejenisnya.

Bahkan, Pasal 389 UU Pemda menegaskan, dalam hal pelaksanaan inovasi yang telah menjadi kebijakan pemda dan inovasi tersebut tak mencapai sasaran yang telah ditetapkan, aparatur sipil negara tak dapat dipidana. Namun, pelaksanaan inovasi itu

mengharuskan dipenuhinya persyaratan prosedur dan substansi yang cukup ketat untuk mencegah penyalahgunaan wewenang dalam pelaksanaan inovasi daerah.

UU AP juga mengatur bahwa
pejabat pemerintah diberi kewenangan menggunakan diskresi dalam pelaksanaan kebijakan.Namun, penggunaan wewenang diskresi tersebut harus didasarkanatas tujuan yang bersifat limitatif, sebagaimana diatur pada Pasal 22 Ayat (2) UU AP, antara lain, melancarkan penyelenggaraan

pemerintahan, mengisi kekosongan hukum, dan mengatasi stagnasi pemerintahan.

Terdapat sejumlah persyaratan ketat dalam penggunaan diskresi, antara lain harus didasarkan alasan-alasan yang obyektif, tidak menimbulkan konflik kepentingan dan didasarkan itikad baik. Diskresi juga tak boleh jadi selubung bagi tindakan sewenang-wenang atau penyalahgunaan wewenang sehingga terdapat prosedur cukup ketat dalam penggunaan wewenang diskresi bagi pejabat pemerintah.

Dalam teori perundangundangan terdapat salah satu asas penting, yaitu asas kesesuaian (congruency) yang bermakna bahwa UU harus diterapkan sesuai dengan tujuan pembentukannya dan harus dicegah perbedaan antara bunyi UU dan penegakannya. Berdasarkan asas tersebut, sejauh norma hukum inovasi daerah dan diskresi diterapkan dalam koridor tujuan pembentukan norma hukum tersebut untuk memperlancar penyelenggaraan pemerintahan di daerah dalam rangka memberikan pelayanan publik kepada rakyat, dapat digunakan sebagai rujukan bagi pemda untuk tak perlu khawatir kebijakan-kebijakannya dikriminalisasi.

\section{Kesimpulan}

Pada prinsipnya UndangUndang Nomor 23 tahun 2014 dan Undang-Undang Nomor 30 tahun 2014 menjadi pedoman kepala daerah untuk berinovasi dan melakukan diskresi tanpa ragu dan takut. Undang Undang Administrasi Pemerintahan menjamin diskresi yang dilakukan kepala daerah, dan memastikan kewenangan untuk mengambil kebijakan saatdiperlukan, untuk mempercepat pembangunan dan kesejahteraanmasyarakat.

Akan tetapi kekuasaandiskresi pemerintah harus tetap beroperasi di bawah suatu sistem hukum yaitu the rule of law. Di bawah preskripsi asas the rule of law 
kekuasaan diskresi pemerintah hidup berdampingan dengan asas the rule of law, kekuasaan diskesi pemerintah hidup berdampingan dengan asas responsible goverment. Dengan demikia, terdapat dasar- dasar pengujian hukum terhadap tindakan diskresi pemerintah, dalam hal ini adalah prinsiples of good governace dan asas-asas efisiensi danefektivitas. Dasar-dasar pengujian yang dikemukakan diatas memiliki tiga fungsi dalam hubungan dengan kekuasaan diskresi pemerintah. Pertama, kompensasi atas hilangnya jaminan dari asas legalitas. Kedua, sebagai dasar argumen bagi tindakan. Ketiga sebagai dasar egitimasi kemasyarakatan yang menuntut adanya fairness dan justice bagi tindakan diskresi pemerintah.

Dalam pengertian demikian maka tindakan diskresi pemerintah tidak boleh menghalalkan segala cara untuk mencapai tujuan yang dicanangkannya meskipun tujuan tersebut legitimate. Dasar-dasar pengujian hukum terhadap tindakan diskresi pemerintah ini aplikabel,baik dalam rangka kontrol yudisial, politik, maupun administratif.

\section{Daftar Pustaka}

Darumurti, Krishna D., 2012. Kekuasaan Diskresi Pemerintah. Bandung. PT. Citra Aditya Bakti.

Faal, M., 1991. Diskresi Kepolisian, Jakarta, PT. Pradnya Paramita

Fatovic, Clement, 2009. Outside the Law : Executive and Emergency Power, Baltimore The John Hopkins University Press

Hornby,A.S. 1983 Oxford Advanced Dictionary, Oxford: Oxford University Press

HR. Ridwan, 2007. Hukum Administrasi Negara, Jakarta, PT RajaGrafindo Persada.

N.M. Spelt \& J.B.J.M. ten Berge dalam Philipus M. Hadjon, 1992 Pemerintahan menurut hukum (Wet-en Rechtmatig Bestuur), Surabaya: Yuridika.

Panjaitan, Saut P., Maksna dan Peranan Freies Ermessen dalam Hukum Administrasi Negara. dalam S.F. Marbun ,et.al. Eds. 2004. Dimensi-Dimensi Pemikiran Hukum Administrasi Negara. Yogyakarta, UII Press.

di Keamatan, M. P. N. S., \& Hulu, S. Evaluasi Pelaksanaan Peraturan Pemerintah Nomor 45 Tahun 2007 Tentang Persyaratan dan Tata Cara Pengangkatan Sekretaris Desa.

Ispik, A., Yogia, M. A., Wedayanti, M. D., \& Zainal, Z. (2021). The Influence of Discipline on Performance of Employees Office of the Ministry of Religion. Pekanbaru City.

Subhayano, T., Yogia, M. A., Wedayanti, A. A. P. M. D., \& Zainal, M. L. H. (2021). Good Governance in Maintaining Peace 
and Order at Pangkalan Kerinci District. Pelalawan Regency.

Ispik, A., Yogia, M. A., Purwati, A. A., Wedayanti, M. D., \& Zainal, M. L. H. (2021). Analysis of Benefits, Discipline and Leadership Style in improving Employee Performance of the Ministry of Religion in Pekanbaru, Indonesia.

Nasri, H., Nurman, N., Azwirman, A., Zainal, Z., \& Riauan, I. (2022). Implementation of collaboration planning and budget performance information for special allocation fund in budget planning in the regional development planning agency of Rokan Hilir regency. International Journal of Health Sciences (IJHS) Ecuador, 6(S4), 639-651.

Munir, A., Wahyudi, S., \& Zainal, Z. (2020). Tinjauan Kriminologi Terhadap Sensual Marketing Sebagai Strategi Pemasaran Produk Yang Diperankan Oleh Sales Promotion Girl Di Kota Pekanbaru. Wedana: Jurnal Kajian Pemerintahan, Politik dan Birokrasi, 6(2), 21-35.

Subhayano, T., Yogia, M. A., Wedayanti, M. D., \& Zainal, Z. (2021). The Role of the Camat in Coordinating the Administration of Peace and Order in Pangkalan Kerinci District Pelalawan Regency.

Suwaryo, H. U., \& Redjo, H. S. I. (2018). Transformasi Hubungan Pemerintah Pusat Dan Pemerintah Daerah Dalam Pemberian Izin Hutan Tanaman Industri Bagi Swasta Di Provinsi Riau Tahun 2010-2015.

Wicaksono, A. (2022, April). Peatlands Restoration Policies in Indonesia: Success or Failure? In IOP Conference Series: Earth and Environmental Science (Vol. 995, No. 1, p. 012068). IOP Publishing.

Yogia, A. S. M. A., Rahman, Z. M. D. W. K., \& Purwati, A. A. (2021). Leadership of Tourism and Culture Department in Development of Cultural Reserves at District Kuantan Singingi.

Zainal, Z., Rambey, R. R., \& Rahman, K. (2021). Governance of Household Waste Management in Pekanbaru City. MIMBAR: Jurnal Sosial dan Pembangunan, 37(2).

Halim, N. A., Rosidi, I., Haris, A., Yesicha, C., \& Riauan, M. A. I. Media dan Politik.

Riauan, M. A. I., Aziz, A., \& Nurman, N. (2020). Analisis Framing" Aksi Bela Islam" sebagai Dakwah Islam di Riau Pos (A Framing Analysis of" Islam Defense Action" as Islamic Dakwah on Riau Pos Newspaper). Jurnal Dakwah Risalah, 31(1), 35-47.

Riauan, M. A. I., Qurniawati, E. F., Aslinda, C., \& Aziz, A. (2020). Konstruksi Realitas Pada Pesan Politik Calon Walikota Pekanbaru di Riau Pos. ETTISAL: Journal of Communication, 5(1).

Riauan, M. A. I., Kholil, S., \& Sikumbang, A. T. (2019). Islamic Symbols on Political Messages in Newspapers in Riau (Study in Regional Head Election 2017). Budapest International Research and Critics InstituteJournal (BIRCI-Journal), 2(1), 254-262.

Riauan, M. A., Sari, G. G., Aslinda, C., \& Qurniawati, E. F. (2018). Konstruksi Makna Ketergantungan dalam Perilaku Merokok. Relasi Negara Industri Dan Masyarakat Dalam Perspektif 
Komunikasi, 171.

Riauan, M. A. I., \& Shasrini, T. (2017). Dampak Komunikasi Terapeutik terhadap Citra Pelayanan Kesehatan (Studi Kasus di Rumah Sakit Umum Daerah Arifin Achmad Pekanbaru). Jurnal The Messenger, 9(1), 31-43.

Riauan, M. A. I. (2016). Figur Politik Calon Walikota Pekanbaru Septina Primawati Rusli dan Erizal Muluk Pada Pemilukada Kota Pekanbaru 2011. Medium, 4(2).

Riauan, M. A. I. (2013). Penggunaan Teknologi Komunikasi dalam Penerapan Good Governance. Jurnal Kajian Pemerintahan, 2(2), 102-107.

Riauan, M. A. I. (2012). Studi Komparatif Aktivitas Humas Antara Pemerintah Provinsi Riau dengan PT. Chevron Pacific Iindonesia. Medium, 1(1).

Sari, G. G., Wirman, W., \& Riauan, M. A. (2018). Pergeseran Makna Tradisi Bakar Tongkang Bagi Generasi Muda Tionghua di Kabupaten Rokan Hilir Provinsi Riau. 